\title{
PEMIKIRAN TEOLOGI ISLAM MODERN PERSPEKTIF SAYYID AHMAD KHAN
}

\author{
Oleh: \\ Endrika Widdia Putri \\ Aqidah dan Filsafat Islam, Pascasarjana UIN Sunan Kalijaga Yogyakarta \\ Email: endrikawiddiaputri@yahoo.co.id
}

\begin{abstract}
This paper departs from the assumption that the study of Islamic theology does not touch aspects of reality, so it is still a hot debate among Islamic thinkers. Although theology has progressed from classical to modern- whose discussion has touched on aspects of reality, this assumption never disappears. If classical Islamic theology is incapable of confronting the problem of reality, then modern Islamic theology is able to answer the problem of reality. Sayyid Ahmad Khan is one of the modern Islamic theologians who contributed his thoughts for the betterment of his people. The concept of modern Islamic theology put forward by Sayyid Ahmad Khan became a revival of the spirit of Islam that was lost in India. This is evidence that theological problems can overcome worldly problems. The thought of modern Islamic theology Sayyid Ahmad Khan is first, placing reason in a high position; this is in line with the thought of Muktazilah. But for him, freedom of reason has limits. Second, human actions. Regarding this Sayyid Ahmad Khan is in line with the understanding of Qadariyyah. According to him, human progress depends on the extent to which humans use the resources that God has given him. Third, the law of cause and effect (sunnatullah), according to him Islam is the religion that is most in accordance with natural law because natural law is God's creation and the Qur'an is His word, of course both are in line and there is no contradiction.
\end{abstract}

Keywords: Modern Islamic Theology, Sayyid Ahmad Khan, Islamic Awakening

\section{A. Pendahuluan}

Pemikiran teologi dalam Islam telah mengalami dua fase perkembangan- teologi Islam klasik dan teo- logi Islam Modern. Secara historis, lahirnya pemikiran teologi Islam klasik dalam Islam tak lepas dari kontestasi politik. Perang Shiffin yang terjadi antara Ali bin Abi Thalib (khalifah ke-4 
al-Khulafa-ur-Rasyidin)

dan Mu'awiyah bin Abi Sufyan (Gubernur Damaskus, Syiria) melatarbelakangi munculnya pemikiran teologi dalam Islam. Perang Shiffin tersebut berakhir dengan tahkim dalam rangka menyelesaikan konflik militer di antara meraka (Amin Nurdin, Sejarah Pemikiran Islam, xxiv:2014). Peristiwa tahkim tersebut menimbulkan yang merugikan di pihak Ali dan menguntungkan di pihak Mu'awiyah, karena menjadikan Mu'awiyah sebagai khalifah yang tidak resmi. Tidak mengherankan keputusan ini ditolak Ali dan tak mau menyerahkan jabatannya hingga akhirnya Ali mati terbunuh (Wiji Hidayati, Ilmu Kalam,117:2017).

Dari peristiwa tersebut muncul golongan yang tidak setuju dengan hasil tahkim tersebut dan menganggap semua yang terlibat dalam tahkim tersebut telah berbuat dosa besar, mereka telah kafir karena tidak lagi berhukum dengan hukum Allah, darah merekapun halal untuk dibunuh (Ris'an Rusli, Teologi Islam, 2:2015). Dari sinilah mulai munculnya pemikiran-pemikiran kalam dalam dunia Islam, dengan bermunculannya aliran-aliran kalam yang membahas persoalan dosa besar, kedudukan akal dan wahyu, free will and predestination, kekuasaan dan kehendak mutlak Tuhan, keadilan Tuhan, perbuatanperbuatan Tuhan, sifat-sifat Tuhan, konsep iman dan lain-lain sebagainya. Kajian-kajian dalam teologi Islam klasik ini tentunya melahirkan perkembangan pemikiran dalam dunia Islam. Hanya saja, bangunan keilmuan teologi Islam klasik nampaknya- pembahasannya hanya berkutat pada persoalanpersoalan langit (In'an Esha, Teologi Islam, 3:2008). Ini menjadi kelemahan teologi Islam Klasik, yang tidak bisa dihadapkan pada masalah-masalah sosial kehidupan (empiric) yang selalu tumbuh dan berkembang serta sejalan dengan pertumbuhan ilmu pengetahuan dan teknologi (Muhaemin Latif, "Membumikan Teologi Islam, Jurnal Dakwah Tabligh, Vol. 14, No. 2:170).

Dalam hal ini, muncullah gerakan pembaharuan dalam dunia Islam, salah satunya untuk membongkar teologi Islam klasik yang selama ini sangat melangit dan tidak menyentuh aspek realitas sedikitpun. Gerakan pembaharuan dalam Islam pada hakekatnya merupakan usaha kritik diri umat Islam dan perjuangan untuk menegaskan bahwa Islam selalu relevan menghadapi situasi-situasi baru yang dihadapi oleh masyarakat Islam (Siti Hardianti, "Pembaharuan Pemikiran Islam" Vol. 1, No. 1, 2016:185). Bermunculannya berbagai pemikiran pembaharuan di blantika pemikiran modern Islam dalam rangka membangun kembali kejayaan Islam yang telah runtuh (In'an Esha, Teologi Islam:11). Teologi Islam modern hadir dengan rekontruksi baru dan mengikuti perkembangan zaman- tidak lagi melangit, serta mampu dihadapkan dengan masalah-masalah sosial.

Di antara pelopor teologi Islam modern adalah Sayyid Ahmad Khan yang berasal dari India. Negara india sendiri dalam perjalanan sejarahnya telah dipengaruhi oleh tiga invasi besar. Invasi bangsa Arya (mulai tahun $1500 \mathrm{SM}$ ), invasi agama Islam (mulai tahun $1000 \mathrm{M}-1700 \mathrm{M}$ ), dan invasi Inggris (mulai $1750 \mathrm{M}$ sampai seabad selanjutnya) (Mohammad Asrori, "Menyingkap Peradaban Islam", Harakah, Vol. 11, No. 3, 2009:235). Sayyid Ahmad Khan hidup pada masa India berada di bawah kekuasaan kerajaan Mongol hingga akhirnya ditaklukan 
oleh Inggris. Ditaklukannya kerajaan Mongol oleh Inggris membuat kondisi umat Islam India tidak stabil dan berada pada fase kemunduran. Hal ini membuat Sayyid Ahmad Khan tergerak hati untuk membangkitkan kembali semangat umat Islam. Ia mengambil langkah berteman dengan Inggris demi mengambil keuntungan yang bermanfaat bagi umat Islam India. Pergaulannya dengan Inggris melahirkan pemikiran-pemikiran yang brilian dan genius, sekaligus mendukung pemikirannya tentang semangat menggunakan akal dalam segala bidang kehidupan. Pemikirannya yang berpatokan pada akal sangat jelas terlihat pada bidang teologi.

Sayyid Ahmad Khan dengan pemikiran teologinya berusaha untuk mendobrak zona nyaman umat Islam India kala itu, yang terlalu enggan untuk menerima peradaban barat- ilmu pengetahuan dan teknologi. Keenganan umat Islam India menerima peradaban yang datang dari Barat inilah menurut Sayyid Ahmad Khan yang menyebabkan kemunduran umat Islam India. Sayyid Ahmad Khan berusaha meyakinkan umat Islam India akan pentingnya ilmu pengetahuan dan teknologi. Ia menyuarakan pentingnya menggunakan akal dalam perkembangan kehidupan manusia. Sayyid Ahmad Khan percaya manusia dengan daya-daya yang diberikan Tuhan kepadanya mampu membuat peradaban baru seperti yang dilakukan Barat. Selain itu, dengan pemikiran hukum sebab akibat (kausalitas) atau sunnatullahnya, Sayyid Ahmad Khan menekankan pentingnya umat Islam India untuk tetap berpatokan pada ide moral.

Berdasarkan penjelasan di atas, penting kiranya mengkaji lebih dalam lagi bagaimana pemikiran teologi Islam
Sayyid Ahmad Khan, yang kala itu berhasil membangkitkan kembali semangat umat Islam India. Dalam hal ini fokusnya akan menjelaskan bagaimana pandangan Sayyid Ahmad Khan mengenai kedudukan akal, perbuatan manusia, dan hukum sebab akibat (kausalitas) atau sunnatullah.

\section{B. Riwayat Hidup}

Sayyid Ahmad Khan dilahirkan di Delhi pada tanggal 17 Oktober 1817 dan menurut keterangan berasal dari keturunan Husein, cucu nabi Muhammad melalui Fatimah dan Ali (Akhmad Taufik, Sejarah Pemikiran, 106:2005). Ia berasal dari keluarga yang cukup terpandang. Ayahnya Mir Muttaqi adalah seorang pemimpin agama dan karena keturunan Sayyid maka ia juga memperoleh pengaruh besar dan sangat dihormati oleh raja Mongol pada waktu itu, Akbar Syah II (Mukti Ali, Alam Pikiran Islam, 54:1996). Adapun kakeknya Sayyid Hadi, adalah seorang panglima perang yang dikemudian hari diberi kedudukan agamais Semi Hakim oleh kaisar Mongol yaitu zaman Alamghir II (1754-1759) (Taufik, Sejarah Pemikiran:106). Kedudukan ayah dan kakeknya menjadikan masa kecil Sayyid Ahmad Khan dilalui dalam kesenangan dan kecukupan, tetapi dengan wafatnya kakeknya, kekayaan keluarga mulai menurun. Pada 1838 ayahnya meninggal dan keuntungan hasil tanah yang diperuntukkan baginya oleh pemerintah mulai hilang atau mulai dikurangi. Sayyid Ahmad Khan yang masih muda itu mulai mencari penghidupannya sendiri (Mukti Ali, Alam Pikiran Islam: 56).

Mengenai pendidikan yang diperolehnya sewaktu kecil tidak terlalu mendalam dan sistematis. Namun, di 
bawah asuhan ibunya yang sangat bijaksana, ia memperoleh pengetahuan yang cukup (Mukti Ali, Alam Pikiran Islam: 56). Ia mendapat pendidikan tradisional dalam pengetahuan agama dan di samping belajar bahasa Arab ia juga belajar bahasa Persia. Ia adalah orang yang rajin membaca dan banyak memperluas pengetahuan dengan membaca buku dalam berbagai bidang ilmu pengetahuan (Harun Nasution, Pembaharuan dalam Islam: 165:1991). Kemudian, ia mendapat pendidikan lanjutan yang kelak menjadikannya figur cendekiawan India dengan kemampuan intelektual di atas rata-rata. Diketahui bahwa di samping mendalami studi keislaman yang lazim dipelajari oleh pelajar India muslim, ia juga mendalami ilmu-ilmu sains, sejarah, matematika, dan fsika. Dengan latar belakang keluarga terpandang dan tingkat pendidikan yang luar biasa ini, tentu saja membantu Ahmad Khan sukses di jenjang karir (Yecki Bus, "Sir Sayyid Ahmad Khan" Turast: Jurnal Penelitian \& Pengabdian, Vol. 3, No. 1,2015:58).

Pada waktu berusia delapan belas tahun, ia bekerja di Serikat India Timur. Ia juga pernah tercatat bekerja sebagai hakim di Departemen Hukum New Delhi. Kemudian ia sempat menempati jabatan di lembaga peradilan di Agra dan Patihpur. Selanjutnya, pada tahun 1846, ia pulang kembali ke Delhi dan mempergunakan kesempatan itu untuk belajar (Abdul Rozak, Ilmu Kalam, 257:2012). Di Delhi ia dapat melihat langsung peninggalanpeninggalan kejayaan Islam dan bergaul dengan tokoh-tokoh dan pemuka Muslim, seperti Nawab Ahmad Baksh, Nawab Mustafa Khan, Hakim Mahmud Khan, dan Nawab Aminuddin. Semasa di Delhi, ia mulai menulis, tulisannya yang pertama adalah Asar as-Sanadid (Abdul Rozak Ilmu Kala: 258). Adapun karya-karyanya selanjutnya yaitu Ain Akbari, the Causes of the India Revolt, the Loyal Mehammadans of India, the Aligarh Institute Gazette, Essays on the Life of Mohammad, Tahzibul Akhlaq (Mukti Ali, Alam Pikiran: 6472).

Usianya yang panjang sekitar 80 tahun, dapat dibagi dalam empat periode. Dua puluh tahun yang pertama adalah masa pendidikannya. Dua puluh tahun berikutnya, 1837-1857, ditandai dengan kesuksesan-kesuksesannya sebagai pegawai peradilan di gabungan provinsi. Dua puluh tahun berikutnya, 1857-1877, merupakan masa minatnya kepada aktivitas kesejahteraan umum, khususnya pendidikan masyarakat Islam. Periode keempat 1877-1898, merupakan masa paling penting dalam hidupnya. Dalam periode inilah ia mendapatkan reputasi sebagai pemimpin politik dan pendidikan Islam India terbesar selama abad 19. Ia menciptakan sarana pendidikan masa panjang bagi negerinya dengan mendirikan The Anglo Mohammadan Oriental College di Aligarh dan perhimpunan ilmuwan, serta mengadakan konferensi pendidikan Islam seluruh India (Jamil Ahmad, Seratus Muslim Terkemuka, 269:1987).

\section{Gerakan Pembaharuannya}

Sir Sayyid Ahmad Khan tumbuh dalam kondisi sosial-kultural di mana pasukan Inggris menguasai India dan menaklukan kerajaan Mongol- kerajaan yang berkuasa pada masa itu, sehingga kerajaan Mongol mandul dan posisi raja hanyalah simbol tanpa otoritas. Raja hanyalah boneka yang menjalankan kebijakan pemerintah Inggris ( ${ }^{1}$ Amroeni Drajat, dkk., "Theology 
Thought :53). Inggris sebenarnya mendatangkan kemajuan bagi India, hanya saja kurangnya kemampuan sumber daya manusia membuat kemajuan tersebut tidak bisa berbaur dengan umat Islam India. Hal ini membuat sikap antipasti terhadap Inggris. Sebaliknya, umat Hindu lebih reseptif terhadap peradaban baru dan lebih baik dalam hal memenuhi standar untuk direkrut sebagai karyawan di kantor pemerintah Inggris (Amroeni Drajat, Theology Thought: 53). Menurut pendapat S. R. Wasti dalam jurnal yang ditulis oleh Belkacem Belmekk Sir Sayyid Ahmad Khan and the Muslim Cause in British India- tujuan Inggris memilih mitra dan kolaborator Hindu adalah untuk menindas umat Islam serta menciptakan kesenjangan yang tidak terjembatani antara kedua komunitas (Belkacem Belmekk, Sir Sayyid Ahmad Khan and the Muslim Cause in British India, Aljazair: Université d'Oran 2 Mohamed Ben Ahmed, 16: 2010). Hal ini memungkinkan terjadi, karena ketakutan Inggris kepada umat Islam jika bangkit kembali yang akan menjatuhkan Inggris dalam nyamannya ia menjajah umat Islam India.

Dominasi Inggris membuat umat Islam India mengalami kecemasan sebagai responnya mereka melakukan pemberontakan berdarah pada tahun 1875 (Mohammad Asrori, "Menyingkap Peradaban Islam": 236). Terjadilah kekacauan politik besar, yang dimulai dengan pemberontakan dari beberapa kesatuan Angkatan Darat India yang kemudian merambah pada penduduk sipil, dan itu menjadi suatu kejadian yang tidak bisa dielakkan bagi rakyat biasa yang tunduk dan patuh untuk berpihak pada konflik yang berdarah itu (Mukti Ali, Alam Pikiran: 58). Sir Sayyid Ahmad Khan yang hidup pada keadaan kekacauan ini menjadikan ia menampakkan eksistensi dan membuat babak baru dalam kehidupannya. Pada saat itu ia berusia 40 tahun, berkerja di pengadilan sebagai wakil hakim di Bijnore dan terkenal sebagai pejabat negeri yang adil dan cakap, di samping sangat memperhatikan kesejahteraan rakyat ia tidak lupa untuk menghabiskan waktu senggangnya dalam kegiatan ilmiah (Mukti Ali, Alam Pikiran:58). Meskipun, pemberontakan 1857 adalah kerjasama antara umat Hindu dan Umat Muslim. Namun, kebencian Inggris lebih besar kepada umat Islam, sebab umat Islam dianggap ingin menghidupkan kembali kerajaan Mongol (Yudian Wahyudi, al-Aghani and Ahmad Khan on Imperialism", 23:2007).

Pada masa pemberontakan 1857 Sayyid Ahmad Khan banyak berusaha untuk mencegah terjadinya kekerasan dan banyak menyelamatkan orang Inggris dari pembunuhan. Hal ini menjadikan ia dianggap telah banyak berjasa bagi Inggris dan Inggrispun membalas jasanya dengan memberikan hadiah, namun ia tolak, kecuali gelar Sir yang ia terima (Harun, Pembaharuan dalam Islam:165). Hubungannya dengan Inggris menjadi baik dan inipun ia pergunakan untuk kepentingan umat Islam India (Harun, Pembaharuan dalam Islam: 165). Ia berusaha meyakinkan pihak Inggris bahwa dalam Pemberontakan 1857, umat Islam tidak memainkan peranan utama. Untuk itu, ia keluarkan brosur yang mengandung pejelasan tentang hal-hal yang membawa pada pecahnya Pemberontkan 1857. Di antara sebab-sebab yang ia sebutkan adalah:

1. Intervensi Inggris dalam soal keagamaan, seperti pendidikan 
agama Kristen yang diberikan kepada yatim piatu di pantipanti yang diasuh oleh orang Inggris, pembentukan sekolahsekolah misi Kristen dan penghapusan pendidikan agama di perguruan-perguruan tinggi.

2. Tidak turut sertanya orangorang India, baik Islam maupun Hindu, dalam lembaga-lembaga perwakilan rakyat adalah hal yang membawa kepada rakyat India tidak mengetahui tujuan dan niat Inggris, mereka anggap Inggris datang untuk mengubah agama mereka menjadi Kristen. Kemudian pemerintahan Inggris tidak mengetahui keluhan-keluhan rakyat India.

3. Pemerintahan Inggris tidak berusaha mengikat tali persahabatan dengan rakyat India, sedang kestabilan dalam pemerintahan bergantung pada hubungan baik dengan rakyat. Sikap tidak menghargai dan tidak menghormati rakyat India, membawa kepada akibat yang tidak baik (Harun, Pembaharuan dalam Islam: 165).

Atas usaha-usahanya dan atas sikap setia yang ia tunjukan terhadap Inggris, Sayyid Ahmad Khan akhirnya berhasil dalam mengubah pandangan Inggris tarhadap umat Islam India. Sementara itu, kepada umat Islam ia anjurkan supaya jangan mengambil sikap melawan, tetapi sikap berteman dan bersahabat dengan Inggris (Harun, Pembaharuan dalam Islam: 167). Barangkali dalam kasus ini ia sebenarnya menagmbil sikap realistis dan mengedapankan akal sehat, karena ia sangat memahami betapa kuatnya militer Inggris yang bila dipaksakan juga untuk melawannya justru akan mem- bawa kehancuran bagi negeri India, dan khususnya umat Islam. Statusnya sebagai keluarga terpandang, berkecukupan, dan terpelajar turut mempengaruhi perubahan pemikiran Ahmad Khan menjadi seorang yang moderat dan akomodatif (Yecki Bus, "Sir Sayyid": 60). Cita-citanya untuk menjalin hubungan baik antara Inggris dan umat Islam, agar dengan demikian umat Islam dapat ditolong dari kemunduran, telah dapat diwujudkan di masa hidupnya (Harun, Pembaharuan dalam Islam: 167). Hal ini tentu tidak mudah bagi Sayyid Ahmad Khan untuk mendapatkan dua kepercayaan sekaligus, dari Inggris dan umat Islam India. Inggris menganggap pemberontakan tahun 1857 disebabkan oleh umat Islam, sementara umat Islam menganggap bahwa mereka adalah korban penindasan Inggris (Filza Waseem, "Sir Sayyid Ahmad Khan and the Identity Formation of Indian Muslims through Education", Vol. 2 (2), 2014: 134).

Setelah bergelut dengan Inggris ia melihat kelebihan dan kekuatan Barat, yaitu dalam hal ilmu pengetahuan dan teknologi. Maka, ia berpendapat bahwa agar umat Islam maju- menguasai ilmu pengetahuan dan teknologi yang diperlukan umat Islam bukanlah bekerja sama dengan Hindu melawan Inggris melainkan menjalin hubungan yang baik dan bekerja sama dengan Inggris (Filza Waseem, "Sir Sayyid Ahmad Khan and the Identity Formation of Indian Muslims through Education", Review of History and Political Science, Vol. 2 (2), June 2014, hlm. 134). Begitupun dalam hal pendidikan umat Islam harus bergabung dengan pendidikan Inggris dan memanfaatkan pendidikan ilmiah yang ditawarkan Inggris (Filza Waseem, "Sir Sayyid": 134). 


\section{Pemikiran Teologi Islam Mod- ern Sayyid Ahmad Khān}

Sayyid Ahmad Khan melihat bahwa kemunduran umat Islam India karena mereka tidak mengikuti perkembangan zaman. Peradaban Islam Klasik telah hilang dan telah timbul peradaban baru di Barat. Dasar peradaban baru ini ialah ilmu pengetahuan dan teknologi. Ilmu pengetahuan dan teknologi modern adalah hasil pemikiran manusia. Oleh karena itu, akal mendapat penghargaan tinggi bagi Sayyid Ahmad Khan. Tetapi sebagai orang Islam yang percaya kepada wahyu, ia berpendapat bahwa kekuatan akal bukan tidak terbatas (Harun, Pembaharuan dalam Islam: 167). Bahkan, C.W. Troll mengambarkan Sayyid Ahmad Khan sebagai neo-Muktazilah, namun Troll menyimpulkan bahwa ketika Sayyid Ahmad Khan membangkitkan kembali ajaran filsafat dalam tulisan-tulisannya, dia melakukannya dalam konteks pandangan dunianya sendiri. Apa yang membuatnya perlu mengadopsi pandangan dunia baru tepatnya adalah karena perkembangan sains modern (John Cooper, dkk., Pemikiran Islam, terj. 12:2000).

Sayyid Ahmad Khan juga melihat bahwa kemunduran umat Islam disebabkan oleh kesalahan dalam memahami agama yang mencampurbaurkan mana yang dinamakan agama dan mana yang dinamakan budaya dan kebiasaan sosial. Dalam Risalahnya yang berjudul Rah i Sunnat (Jalan Sunnah) seperti yang dikutip dari jurnal yang berjudul Religious Thought of Sir Sayyid

Ahmad Khan oleh Mazheruddin Siddiqi, Sayyid Ahmad Khan Mengatakan bahwa:
"Risalah ini menyangkut dua hal. Pertama, yang menyangkut ajaran Islam dan cara ibadah, inilah yang sekarang saya sebut sebagai agama. Kedua, yang menyangkut budaya dan kebiasaan sosial, seperti cara makan, minum, berpakain, berurusan dengan orang lain bukan kategori agama. Saya menganggapnya sebagai kesalahan besar (untuk memasukkan hal-hal itu dalam agama). Faktanya adalah bahwa sejak dimulainya karir pendidikan saya, ide telah tertanam dalam diri saya bahwa agama berkaitan dengan din (masalah agama) dan dunia, dan ketika saya menulis Risalah ini saya masih di bawah kesan yang sama. Oleh karena itu, saya menulis tentang din dan dunia (tanpa membuat batasan di antara keduanya). Setelah banyak berpikir dengan hati-hati dan setelah merenungkan perintah Allah dan Nabi, saya belajar untuk membuat perbedaan antara keduanya. Sekarang saya berpikir bahwa adalah kesalahan besar untuk tidak membedakan antara hal-hal yang berkaitan dengan din dan halhal yang berkaitan dengan dunia dan memperlakukan mereka pada tingkat kesetaraan seolah-olah keduanya merupakan agama"( Mazheruddin Siddiq, "Religious Thought of Sir Sayyid Ahmad Khan", Islamic Studies, Vol. 6, No. 3. 1967:294).

Dari perkataan Sayyid Ahmad Khan tersebut dapat dijelaskan bahwa selama ini umat Islam sering men- 
campurbaurkan hal-hal pokok dan cabang dalam Islam. Sayyid Ahmad Khan sendiri mengaku juga demikian, ketika ia masuh kecil hingga ia menulis risalahnya tersebut, ia masih dalam pandangan yang sama. Walau akhirnya ia tersadar bahwa memcampurbaukan antara ajaran Islam dan cara ibadah (agama) dengan urusan keduniawianbudaya dan kebiasaan sosial adalah kesalahan yang besar, apalagi sampai menyetarakan antara keduanya. Pemahaman seperti ini tentu akan melahirkan kekakuaan dalam agama yang membuat tidak berkembanganya studi kajian keislaman.

Lebih lanjut, mengenai teologi Sayid Ahmad Khan sebagaimana dikutip Fazlur Rahman dalam jurnal yang ditulis oleh Gunawan B. Dulumina yang berjudul Gerakan Pembaruan Sayid Ahmad Khan, mengatakan bahwa:

Seperti sebelumnya, sekarang ini, kita memerlukan suatu teo$\log i$

(ilmu kalam) yang modern, yang dengannya kita mesti menolak

doktrin sains-sains modern, atau meruntuhkan fondasifondasinya, ataupun juga menunjukkan bahwa sainssains tersebut adalah sesuai dengan Islam. Apabila mau menyebarkan sains-sains tersebut di kalangan kaum muslimin, tentang hal mana, saya baru saja katakan, betapa banyak sains yang tidak bersesuaian dengan Islam masa kini, maka adalah merupakan tugas saya untuk mempertahankan Islam sebanyak yang saya mampu, baik secara benar ataupun secara keliru, dan mengungkapkan kepada masyarakat wajah Islam yang asli dan semerlang. Hati nurani saya mengatakan bahwa bila saya tidak melakukan hal ini, saya akan menjadi seorang yang berdosa di hadapan Tuhan"( Gunawan B. Dulumina, "Gerakan Pembaruan Sayid Ahmad Khan", Jurnal Hunafa, Vol. 2 No. 2. 2005: 161-162).

Ada fase di mana Sayyid Ahmad Khan merasa frustasi jika ia tak ikut andil dalam kemerosotan pemikiran dan kemunduran umat Islam pada masa itu. Ia sampai menyebut berdosa jika tak membangkitkan kembali semangat umat Islam India. Bahkan, ia menyebut merupakan tugasnya untuk mempertahankan Islam sebanyak yang ia mampu, dengan kebenaran ataupun kekeliruan. Ia melihat penting bagi umat Islam India untuk mengaitkan hidupnya dengan perkembangan sains dan teknologi.

Sayyid Ahmad Khan percaya pada kekuatan kebebasan akal, sungguhpun mempunyai batasan. Baginya, manusia memiliki kebebasan dan kemerdekaan dalam menentukan kehendak dan melakukan perbuatan. Dalam kata lain, ia mempunyai paham Qadariyah (free will and free act) dan tidak paham Jabariyah atau Fatalisme. Manusia menurut pendapatnya, dianugerahi Tuhan daya-daya, di antaranya daya berpikir, yang disebut akal, dan daya fisik untuk mewujudkan kehendaknya. Manusia mempunyai kebebasan untuk mempergunakan daya-daya yang diberikan Tuhan kepadanya (Harun, Pembaharuan dalam Islam: 167-168). Oleh sebab itu, kemajuan manusia bagi Sayyid Ahmad Khan tergantung pada sejauh mana manusia 
menggunakan daya-daya yang dianugerahi Tuhan tersebut.

$$
\text { Adapun pandangannya }
$$

mengenai hukum alam (kausalitas / sebab akibat) atau yang ia sebut dengan istilah nature- sejalan dengan paham qadariyah yang dianutnya, ia percaya bahwa bagi setiap makhluk, Tuhan telah menentukan tabi'at atau naturnya. Natur yang ditentukan Tuhan ini dan yang di dalam al-Qur'an yang disebut Sunatullah, tidak berubah (Harun, Pembaharuan dalam Islam: 167-168). Islam adalah agama yang paling sesuai dengan hukum alam karena hukum alam adalah ciptaan Tuhan dan alQur'an adalah firman-Nya, sudah tentu keduanya sejalan dan tidak ada pertentangan (Abdul Rozak, Ilmu Kalam: 259). Dalam hal ini, Sayyid Ahmad Khan memiliki standar sendiri untuk menguji kebenaran atau validitas suatu agama. Jika agama sesuai dengan kodrat manusia atau hukum kodrat pada umumnya, maka itulah agama yang benar (Amroeni "Theology Thought of Sir Sayyid Ahmad Khan”: 55).

Mengenai agama itu pasti sesuai dengan fitrah manusia John J. Donohue dan John L. Esposito mengomentari pemikiran Sayyid Ahmad Khan tersebut- menurutnya dari pemikiran Sayyid Ahmad Khan tersebut ia ingin mengedepankan Islam adalah agama rasional dan fitrah. Ia mengatakan bahwa:

"Satu-satunya ukuran untuk menilai kebenaran agamaagama ialah apakah agama yang dipersoalkan itu sesuai dengan fitrah manusia atau dengan alam. Jika sesuai maka agama itu benar dan adanya persesuaian tersebut merupakan tanda bahwa agama itu benar-benar diturunkan oleh
Tuhan yang telah menciptakan manusia. Tetapi, jika ternyata agama itu bertentangan dengan fitrah manusia atau dengan hukum-hukum kealaman yang berlaku, serta tidak sesuai dengan kekuatan dan anggotaanggota jasmaninya atau menghambat manusia untuk memanfaatkan sarana-sarana tersebut, maka tak dapat diragukan lagi bahwa agama itu diciptakan oleh sesuatu yang tidak menciptakan manusia itu, sebab semua orang sependapat bahwa agama pada dasarnya diperuntukkan bagi manusia" (John J. Donohue dan John L. Esposito, Islam dan Pembaharuan, terj: 63:1989).

Dari kutipan tersebut dapat dipahami bahwa agama yang benarbenar berasal dari Tuhan adalah agama yang sesuai dengan fitrah dan akal manusia. Artinya agama tersebut dapat pernah lepas dari kodrati manusia atau bertentangan dengan hukum alam dan ia selalu mampu relevan sepanjang zaman. selalu ada interpresi baru yang mampu membuatnya dipertahankan dan selalu diamalkan oleh penganutnya.

Pada 21 Januari 1870 Sayyid Ahmad Khan menulis surat kepada Muhsin al-Mulk:

"Jika orang tidak menghindari mengikuti kebutaan, jika mereka tidak secara khusus mencari cahaya yang dapat ditemukan dalam al-Quran dan Hadits yang tidak terbantahkan (kebenarannya), dan tidak menyesuaikan agama dan ilmu pengetahuan saat ini, Islam akan punah di India" (Aziz Ahmad, "Sayyid Aḥmad Khan, 
Jamal al-din al-Afghani and Muslim India”, Studia Islamica, No. 13, 59:1960).

Ini artinya bagi Sayyid Ahmad Khan penting bagi umat Islam India pada saat itu, keluar dari zona nyamannya akan kebencian terhadap Inggris pada masa itu, dan memilih berteman dengan Inggris agar mendapatkan keuntungan darinya. Oleh karenanya Sayyid Ahmad Khan dikenal sebagai salah satu tokoh terkemuka umat Islam India yang melawan tradisi lama masyarakat India (Aziz Ahmad, "Sayyid Ahmad Khan:59) dan menghadirkan pembaharuan bagi umat Islam India. Antara ilmu pengetahuan sebagai peradaban kemajuan Inggris dan al-Qur'an dan Hadits sebagai kekuatan umat Islamkeduanya harus disesuaikan sehingga menghasilkan interpretasi-interpretasi baru yang sesuai dengan perkembangan zaman.

Pandangan Sayyid Ahmad Khan mengenai hukum alam atau sunnatullah tidaklah sama dengan paham kealaman di Barat atau naturalisme Barat, yang mana di Barat- mengenai hubungan Tuhan dengan manusia itu laksana hubungan arloji dengan pembuatnya. Arloji akan berjalan terus secara mekanik tanpa ada hubungan lagi dengan si pembuat. Apa yang diprogramkan si pembuat itulah ketetapan yang mesti dijalaninya. Bagianbagian dalam mesin arloji itulah yang menjalankan fungsinya. Begitu juga dengan manusia, ia tidak berbeda dengan arloji. Manusia akan bergerak secara mekanis sesuai dengan hukum alam itu, yang secara tidak langsung tidak lagi berhubungan dengan si pembuat, terutama dalam menjalankan fungsi-fungsi yang sudah digariskannya (Taufik, Sejarah Pemikiran:110).
Naturalisme Barat menghilangkan Tuhan dalam hukum sebab akibat. Tuhan tidak ada campur tangan dalam segala hal yang terjadi. Sedangkan, dalam pandangan Sayyid Ahmad Khan Tuhan memang menciptakan hukum alam sesuai tabiatnya dan berjalan sesuai hukum tersebut. Namun, tidak menghilangkan keyakinan bahwa Tuhan yang mengatur semuanya, walau Tuhan telah menciptakan hukum sunnatullah sejak azali.

Lebih lanjut, terhadap hukum alam menurutnya, tidak banyak yang dapat ditemukan secara langsung di dalam al-Qur'an dan Sunnah. Begitu juga tentang hubungan manusia dengan manusia, dalam perilaku ekonomi, sosial budaya yang banyak diungkapkannya, hanyalah gambaran masyarakat primitif zaman nabi, maka untuk zaman sekarang hal-hal itu tidak sesuai lagi dengan tuntunan zaman. Itulah sebabnya dalam masalah umum dan duniawi, umat Islam harus belajar banyak kepada Barat dan menerima kebudayaan mereka saat ini dianggap sangat maju kalau umat Islam ingin seperti mereka (Taufik, Sejarah Pemikiran:110). Mengenai kesesuaian antara ilmu-ilmu modern dengan alQur'an, Sayyid Ahmad Khan mendefenisikan lima belas prinsip tafsir alQur'an. Prinsip-prinsipnya ini ditunjukkan secara garis besar dalam rangkaian surat menyuratnya dengan Nawab Mushin al-Mulk pada tahun 1892, dan dihimpun di bawah judul Tahrir fi Usul al-Tafsir. Derek Hopwood $^{1}$ menjelaskan dua poin utama tentang isi buku Sayyid Ahma Khan tersebut. Pertama, bahwa Sayyid Ahmad Khan berpandangan bahwa

Khan.
${ }^{1}$ Orientalis pengkaji Sayyid Ahmad 
karya Tuhan dalam kenyataannya sama dengan hukum alam dalam sains modern. Kedua, kriteria yang ditetapkan untuk memutuskan apakah ayat-ayat tertentu dalam al-Qur'an akan ditafsirkan secara metaforis ataupun tidak, hal ini dilakukan untuk menyesuaikan ayat-ayat tersebut dengan kebenaran ilmiah dalam ilmu pengetahuan alam.

Sejalan dengan keyakinan tentang kekuatan akal dan hukum alam, Sayyid Ahmad Khan tidak ingin pemikirannya terganggu otoritas hadits dan fiqh. Segala sesuatu diukurnya dengan kritik rasional. Ia pun menolak semua yang bertentangan dengan logika dan hukum alam. Ia hanya ingin mengambil al-Qur'an sebagai pedoman bagi Islam, sedangkan yang lain hanya bersifat membantu dan kurang begitu penting (Abdul Rozak, Ilmu Kalam:259). Sebab menurutnya, hadits itu berisi moralitas sosial dari masyarakat Islam abad pertama atau kedua sewaktu hadits tersebut dihimpun, dan hukum fiqh yang berisi perkembangan moralitas pada masyarakat waktu itu hingga munculnya mazhab-mazhab. Makanya, ia menolak taklid dan membawa al-Qur'an untuk direlevansikan dengan perkembangan zaman baru (Mukti Ali, Alam Pikiran Islam Modern: 20).

Taklid inilah menurut Sayyid Ahmad Khan salah satu penyebab umat Islam India mundur karena mereka tidak mengikuti perkembangan zaman. Gaung peradaban Islam Klasik masih melenakan mereka, sehingga tidak menyadari bahwa peradaban baru telah muncul di Barat. Peradaban baru timbul dengan berdasarkan ilmu pengetahuan dan teknologi. Inilah penyebab utama bagi kemajuan dan kekuatan orang Barat(Abdul Rozak, Ilmu Kalam:259). Ia juga mengkritik ulama pada masanya terkhususnya di India, yang tidak mau bangkit dari kehancuran, sehingga ia mengkampanyekan terbukanya pintu ijtihad (Muda, "The Interpretation of the Birth of Jesus" :23).

Dari pemikiran Sayyid Ahmad Khan mengenai hukum alam atau yang ia sebut dengan nature, di satu sisi ia mencoba menunjukkan bahwa ilmu pengetahuan alam dan temuantemuannya sebenarnya sesuai dengan iman Islam, tetapi ia juga berpendapat bahwa sains dan agama sebenarnya berhubungan dengan wilayah-wilayah yang sepenuhnya berbeda- sehingga ilmu dan agama tidak bertentangan maupun bertikai satu sama lain (John Cooper, Pemikiran Islam dari: 11).

Pandangan Sayyid Ahmad Khan mengenai hukum alam ini mengantarkan ia mendapatkan cap murtad oleh Jamaluddin al-Afghani, padahal pemikiran antara keduanya sejalan. Jamaluddin al-Afghani menganggap bahwa Sayyid Ahmad Khan telah berpaham naturalisme dan materialisme. Jamaluddin al-Afghani menuliskan dalam kitabnya ar-Radd 'ala ad-Dahriyin (Penolakan terhadap Kaum Ateis):

"Ketika kami memperhatikan keadaan agama di India pada tahun 1879, kami merasakan adanya kelemahan akal manusia di sana karena bujukan-bujukan yang batil dan sesat. Maka, kami menulis sebuah risalah tentang paham mereka yang rusak itu dan kami menyatakan bahwa agama adalah dasar kebudayaan dan kemajuan" (Muhammad al-Bahiy, Pemikiran Islam Modern, terj. 6:1986).

Ali Rahnema menyebut bahwa, selain karena pemikiran naturalisme Sayyid Ahmad Khan, serangan Jamaluddin al-Afghani terhadapnya bukan 
karena ia adalah pembaharu, namun karena ia pro-Inggris (Ali Rahnema, Para Perintis Zaman Baru Islam, terj. 25:1996).

Serangan ini terjadi bisa saja karena konsekuensi dari pandangan pan-Islamisme Jamaluddin al-Afghani, yang menganggap bahwa tidak adanya kebersatuan di antara umat Muslim, dan ini merupakan titik strategis yang digunakan oleh kolonialisme Barat untuk menjajah dan sedapat mungkin mengeruk kekayaan negara-negara Islam. Lemahnya pendidikan dan kurangnya pengetahuan umat terhadap ilmu-ilmu Islam sendiri bahkan dan juga ilmu-ilmu lainnya menjustifikasi bahwa semangat intelektual yang sangat diagung-agungkan oleh Islam pudar kala itu (Akmal Hawi, "Pemikiran Jamaluddin Al-Afghani (Jamal ad-Din al-Afghani) (1838 - 1897 M)", Medina-Te, Vol. 16, No. 1. 2017:12). Kesalahanpahaman tampaknya telah terjadi antara Sayyid Ahmad Khan dan Jamaluddin al-Afghani, hal ini bisa saja karena provokator yang menginginkan antara keduanya tak saling paham. Apa yang dikedepankan Sayyid Ahmad Khan tak lebih hanya untuk kemajuan umat Islam India, walau dengan pemikiran-pemikiran yang melampaui zamannya dengan menggaungkan kebebasan berpikir yang saat itu kurang dimiliki oleh umat Islam India.

Selain itu, John Cooper juga mengomentari pemikiran naturalisme Sayyid Ahmad Khan, ia menyebut bahwa:

"Sayyid Ahmad Khan terombang-ambing antara klaim iman Islam bisa didamaikan dengan sains modern, dan klaim bahwa ruang lingkup keduanya demikian berbeda, karena agama berhadapan dengan masalah spiritual sementara sains berhadapan dengan masalah keduniawian, sehingga tidak perlu didamaikan. Pernyataan yang kontradiktif ini mencerminkan pergeseran pengertian sains dan keimanan itu sendiri. Perubahanperubahan istilah kunci ini menandakan sifat akal pencerahan modern yang cepat berubah. Bagi Sayyid Ahmad Khan ada kaitan erat antara sifat kebenaran ilmiah yang berubah itu sendiri dan kebutuhan untuk menafsirkan kembali al-Qur'an dengan tafsir baru. Namun, yang menarik di sini adalah walaupun ada kecenderungan pembenaran total terhadap ilmu-ilmu alam dalam tulisannya, dia sadar atas sifat kebenaran ilmiah yang terus berubah. Dengan kata lain, sifat berubah dari istilah sains adalah bagian dari krisis sains, dan tentunya keberanian keilmuan Sayyid Ahmad Khan bisa dibaca lebih bermanfaat dalam pengertian-pengertian problematika yang ada terhadap pembenaran sains bagi pandangan dunia keagamaan di India akhir abad ke-19"'( John Cooper, Pemikiran Islam: 16-17).

Memahami kutipan di atas melahirkan pemikiran bahwa Sayyid Ahmad Khan telah berhasil membangkitkan semangat Islam di India dengan menyatukan dua hal yan berbeda, antara agama yang berkaitan dengan hal spiritual dan sains yang berkaitan dengan keduniawian. Walau berbeda namun ada kaitan erat antara keduanya. Kebenaran sains yang mengalami perkembangan membuat pentingnya akan kebutuhan menafsirkan kembali al-Qur'an dengan tafsir baru. Sifat sains yang berubah tersebut merupakan krisis sains, dan hal ini bermanfaat untuk membaca promblematika keagamaan di India akhir abad ke-19. Bahkan tidak memungkinkan bermanfaat pula untuk memahami prob- 
lematika keagaamaan pada abad sekarang ini.

\section{E. Penutup}

Berdasarkan pembahasan di atas dapat disimpulkan bahwa pemikiran teologi Sayyid Ahmad Khan hadir karena melihat kemunduran umat Islam India yang jauh ketinggalan dari Barat, sehingga Sayyid Ahmad Khan memberanikan diri membuat keputusan berteman dengan Barat dengan tujuan mendapatkan keuntungan yang bermanfaat bagi umat Islam India. Apa yang dilakukannya ini berhasil membuat posisi umat Islam menjadi lebih baik lagi. Puncaknya dengan ia mampu mendirikan sekolah The Anglo Mohammadan Oriental College di Aligarh yang sangat membantu sekali perkembangan pemikiran umat Islam India.

Adapun pemikiran teologi modern Sayyid Ahmad Khan yaitu: pertama, kedudukan akal dalam pan-

\section{Daftar Kepustakaan}

Ahmad, Aziz. 1960. "Sayyid Aḥmad Khan, Jamal al-din al-Afghani and Muslim India". Studia Islamica. No. 13. Dalam https://www.jstor.org/stable/ 1595240?seq.

Ahmad, Jamil. 1987. Seratus Muslim Terkemuka. Terj. Tim Penerjemah Pustaka Firdaus. Jakarta: Pustaka Firdaus.

Al-Bahiy, $\quad$ Muhammad. 1986. Pemikiran Islam Modern. Terj. Su'adi Sa'ad. Jakarta: Pustaka Panjimas. dangan Sayyid Ahmad Khan sejalan dengan Muktazilah, yang menempatkan akal pada kedudukan tinggi. Meskipun akal memiliki batasan menurutnya, yang mana secara umum akal dapat mengetahui empat hal dalam kajian teologi, namun secara rinci akal membutuhkan nash. Kedua, mengenai perbuatan manusia sejalan dengan paham Qadariyyah, bahwasanya manusia memiliki kebebasan dan kemerdekaan dalam menentukan kehendak dan perbuatannya. kemajuan manusia bagi Sayyid Ahmad Khan tergantung pada sejauh mana manusia menggunakan daya-daya yang dianugerahi Tuhan tersebut. Ketiga, terkait dengan pandangannya mengenai hukum sebab akibat / kausalitas (sunnatullah) menurutnya Islam adalah agama yang paling sesuai dengan hukum alam karena hukum alam adalah ciptaan Tuhan dan al-Qur'an adalah firman-Nya, sudah tentu keduanya sejalan dan tidak ada

pertentangan.

Ali, Mukti. 1996. Alam Pikiran Islam Modern di India dan Pakistan. Bandung: Penerbit Mizan.

Asrori, Mohammad. 2009. "Menyingkap Peradaban Islam Kontemporer di Anak Benua India". ElHarakah, Vol. 11, No. 3. Dalam http://103.17.76.13/index. php/infopub/article/view/438.

Belmekk, Belkacem. 2010. Sir Sayyid Ahmad Khan and the Muslim Cause in British India. Aljazair: Université d'Oran 2 Mohamed Ben Ah- 
med.

Dalam

https://www.researchgate.net/pu blication/312587237_Sir_Sayyid_A hmad_Khan_and the Muslim Cause in_British_India/link/5d 3f33c9299bf1995b55fc33/down load,.

Bus, Yecki. 2015. "Sir Sayyid Ahmad Khan Dan Rekonstruksism Pendidikan Islam Ala India". Turast: Jurnal Penelitian \& Pengabdian. Vol. 3. No. 1. Januari - Juni. Dalam https://ejournal.uinib.ac.id/jurna 1/index.php/turast/article/view/ 375/252.

Cooper, John dkk. 2000. Pemikiran Islam dari Sayyid Ahmad Khan hingga Nasr Hamid Abu Zayd, terj. Wakhid Nur Efendi, (Jakarta: Penerbit Erlangga.

Donohue John J, dan John L. Esposito. 1989. Islam dan Pembaharuan: Ensiklopedi Masalah-masalah, terj. Machnun Husein. Jakarta: Rajawali.

Drajat, Amroeni dkk. 2019. "Theology Thought of Sir Sayyid Ahmad Khan", IOSR Journal Of Humanities And Social Science (IOSR-JHSS). Vol. 24. Issue 1. Ser. 8 (January). Dalam https://www.academia.edu/3827 1761/Theology ThoughtofSirSayyidAhmad_Khan

Dulumina, Gunawan B. 2005. "Gerakan Pembaruan Sayid Ahmad Khan". Jurnal Hunafa. Vol. 2 No. 2 Agustus. Dalam https://www.jurnalhunafa.org/in dex.

php/hunafa/article/view/309.

Esha, Muhammad In'an. 2018. Teologi Islam: Isu-isu Kontemporer. Malang: UIN-Malang Press.

Hardianti, Siti. 2016. "Pembaharuan Pemikiran Islam menurut Sayyid Amir Ali Di India". AlLubb. Vol. 1, No. 1. Dalam http://jurnal.uinsu.ac.id/index.p $\mathrm{hp} / \mathrm{lubb} /$ article/view/523.

Hawi, Akmal. 2017. "Pemikiran Jamaluddin Al-Afghani (Jamal adDin al-Afghani) (1838-1897 M)". Medina-Te. Vol. 16. No. 1. Juni. Dalam http://jurnal.raden fatah.ac.id/index.php/medinate/art icle/view/1536.

Hidayati,Wiji. $2017 . \quad$ Ilmu Kalam:Pengertian, Sejarah, dan Aliran-alirannya. Yogyakarta: Program Studi Manajemen Pendidikan Islam.

Latif, Muhaemin. 2013. "Membumikan Teologi Islam dalam Kehidupan Modern (Berkaca dari Mohammed Arkoun)". Jurnal Dakwah Tabligh. Vol. 14. No. 2. Desember. Dalam http://journal.uinalauddin.ac.id/i ndex.php/tabligh/article/ view/325.

Nasution, Harun. 1991. Pembaharuan dalam Islam: Sejarah Pemikiran dan Gerakan. Jakarta: Bulan Bintang. 
Nurdin, M. Amin. 2014. Sejarah Pemikiran Islam: Teologi Ilmu Kalam. Jakarta: Amzah.

Rahman, Muda Ismail Abd. 2003. "The Interpretation of the Birth of Jesus and his Miracles in the Writings of Sir Sayyid Ahmad Khan". Islam and ChristianMuslim Relations. Vol. 14, No. 1. Dalam https://www.tandfonline.com/d oi/ abs/10.1080/09596410305259.

Rahnema, Ali. 1996. Para Perintis Zaman Baru Islam, terj. Ilyas Hasan, (Bandung: Penerbit Mizan.

Rozak, Abdul dan Rosihon Anwar. 2012. Ilmu Kalam. Bandung: CV. Pustaka Setia

Rusli, Ris'an 2015. Teologi Islam: Telaah Sejarah dan Pemikiran Tokoh-tokohnya. Jakarta: Prenadamedia Group.
Siddiq, Mazheruddin. 1967. "Religious Thought of Sir Sayyid Ahmad Khan". Islamic Studies. Vol. 6. No. 3 (September). Dalam https://www.jstor.org/stable/ 20832887.

Taufik, Akhmad. 2005. Sejarah Pemikiran dan Tokoh Modernisme Islam. Jakarta: PT RajaGrafindo Persada.

Wahyudi, Yudian. 2007. Al-Aghani and Ahmad Khan on Imperialism: Comparison from the Perspective of Islamic Legal Philosophy. Yogyakarta: Nawesea Press.

Waseem, Filza. 2014. "Sir Sayyid Ahmad Khan and the Identity Formation of Indian Muslims through Education". Review of History and Political Science. Vol. 2 (2). June. 